\section{$\bullet$ \\ High Therapeutic Properties of Honey from the Borneo Stingless Bee, Heterotrigona itama}

IJCRR

Section: Healthcare

ISI Impact Factor

(2019-20): 1.628

IC Value (2019): 90.81

SJIF (2020) $=7.893$

\section{Ngaini Z, Kelabo ES, Hussain H, Wahi R}

Faculty of Resource Science and Technology, Universiti Malaysia Sarawak, 94300 Kota Samarahan, Sarawak, Malaysia.

\title{
ABSTRACT
}

Introduction: Stingless bee acts as a pollinator and is commonly found in tropical dry and humid forest. Various phenolic compounds have been reported in stingless bee honey which gave antibacterial, antifungal, and antiviral properties.

Objective: The current study focuses on the chemical profiling of honey from Heterotrigona itama on Borneo and evaluation for potential therapeutic properties.

Methods: The honey was extracted via liquid-liquid extraction method and analyzed using spectroscopic methods.

Results: Strong fatty alcohol signals (3.5-4.5 ppm) indicated significant markers in 1H-NMR. The honey demonstrates excellent antibacterial activity against Escherichia coli (E. coli) $(19.0 \mathrm{~mm})$ and stronger antioxidant properties (IC50 $33.78 \mathrm{ppm})$ compared to the Tualang honey (54.90 ppm). Bornean $\mathrm{H}$. itama honey produced lower glucose $(61.65-147.44 \mathrm{~g} / \mathrm{L})$ and heavy metals content (0.003-0.204 ppm) which is significant in food products.

Conclusion: The phenolic, aliphatic acids and fatty alcohols identified in honey contributing to excellent biological properties. This study demonstrated that Borneo $H$. itama honey is a potential source of antimicrobial and antioxidant agents.

Key Words: Antibacterial, Antioxidant, Chemical profiling, Turbidimetry

\section{INTRODUCTION}

Borneo is one of the world's largest tropical forests island. Its humid tropical climate is one of the world's biodiversity hotspots and home to many resin-secreting Dipterocarpaceae trees, which provide an excellent condition for stingless bees to thrive. ${ }^{1}$ The strategic location of Borneo, in particular Sarawak, with dipterocarp and Palmae forests, dense canopy and relatively undisturbed flora could be associated with excellent properties of honey with high anti-oxidant activity and low environmental contaminant. ${ }^{2}$ Around 30 species of stingless bees or kelulut have been found on Borneo, in particular Sarawak, from which H. itama is one of the typical indigenous species reported. ${ }^{3} H$. Itama species are less receptive to changes in season and capable of surviving in rough environments. ${ }^{4}$ Significantly, H. itama has been reported to produce high quality of honey and nutrient compared to other species of stingless bee. ${ }^{3}$
Stingless bee acts as a pollinator and is commonly found in tropical dry and humid forest. ${ }^{5}$ The diminutive size of stingless bees offers advantages to retrieve pollen and nectars more efficiently from small-size plants and a higher number of flowers..$^{6-8}$ Due to its high nutrition and therapeutic properties, chemical profiling study of honey from the stingless bee has received much attention and high market demand. ${ }^{2,9}$ Various phenolic compounds have been reported in stingless bee honey which gave antibacterial, antifungal, and antiviral properties. ${ }^{10}$ Honey rendered by $H$. itama has been reported to have greater antioxidant property than Manuka honey made by Apis mellifera honey bees. ${ }^{9}$ The medicinal property of honey is associated with floral resources..$^{10,11}$

Honey is reported to be of excellent quality based on the physicochemical properties and originality from its botanical, geographical and entomological origins. ${ }^{12}$ The composition of honey is varied and significantly influenced by the climatic conditions as well as plant bio- and chemotype. ${ }^{13}$

\section{Corresponding Author:}

Ngaini Z, Faculty of Resource Science and Technology, Universiti Malaysia Sarawak, 94300 Kota Samarahan, Sarawak, Malaysia. Email: nzainab@unimas.my

ISSN: 2231-2196 (Print) ISSN: 0975-5241 (Online)

Received: 18.10 .2020

Revised: 14.11 .2020

Accepted: 16.12 .2020

Published: 23.02 .2021 
Nevertheless, despite the dense canopy and undisturbed flora and fauna, chemical profiling of chemical constituents of honey from H. itama in Sarawak has not been evaluated and reported.

Herein, we report on the chemical properties, sugar and heavy metal contents of honey from $H$. itama stingless bee, a typical species available in Serapi Garden on Borneo. The spectroscopy analysis of honey from the Bornean stingless bees $H$. itama could be used for possible chemical markers and purity authentication of the stingless bee's honey for potential therapeutic properties.

\section{MATERIALS AND METHOD}

\section{Instrumentation}

Gas chromatography-mass spectrometry (GC-MS) was performed using Shimadzu GC-MS- QP2010 Plus and nonpolar BPX-5-column $(0.25 \mathrm{um}$ x $30 \mathrm{~m}$ x $0.25 \mathrm{~mm})$ (Japan). HighPerformance Liquid Chromatography (HPLC) was conducted using Shimadzu/LC-20A in the presence of RID-10A refractive index detector, CTO-20A column oven, CBM-20A communication bus module and computer controller from Japan. Heavy metals analysis was characterized using Perkin Elmer Inductively Coupled Plasma Optical Emission Spectrometer (ICP-OES, Optima 8000). ${ }^{1} \mathrm{HNMR}$ spectra were recorded on JEOL ECA 500 spectrometer, with chemical shift relative to $\mathrm{CDCl}_{3}-d 6$ as a reference and the chemical shifts were reported in $\delta \mathrm{ppm}$.

\section{Sample collection}

Stingless bees honey samples were collected from Serapi Garden, located at Sarawak in Borneo with coordinates: $1.4273^{\circ}$ $\mathrm{N}, 110.3157^{\circ} \mathrm{E}$. The samples were collected from nests with three different conditions. Two predominant flowering plants at the location were identified as Averrhoa carambola and Antigonon leptopus. The samples were appropriately labelled, with sample code SG01 for the nest that was under the tree and near to herbal plants, SG02 for the nest that was under plant canopy and next to flowering plants and lastly, SG03 for the nest that was near to flowering plants with direct sunlight. All samples were stored in $-20^{\circ} \mathrm{C}$ until further analysis.

\section{Organic Extraction of honey}

Liquid-liquid organic extraction of honey was carried out using hexane and ethyl acetate. ${ }^{14}$ The extraction was performed continuously on a single sample. Honey $(1 \mathrm{~mL})$ was diluted with distilled water $(1 \mathrm{~mL})$ in a glass vial. Hexane was added and the organic phase was extracted ( $2 \times 2 \mathrm{~mL}$ ). The aqueous layer was subsequently extracted with ethyl acetate $(2 \mathrm{x}$ $2 \mathrm{~mL}$ ), and the organic layer was separated. The separated organic layers were transferred to a new glass capped vials each, dried in magnesium sulfate and filtered for GC-MS analysis.

\section{Plant ethanolic extraction}

Predominant flowers of A. carambola and A. leptopus were collected from Serapi Garden. The flowers were cleaned and dried in open air condition before extraction. Dried $A$. $\mathrm{Ca}$ rambola flower $(2 \mathrm{~g})$ and A. leptopus flower $(2 \mathrm{~g})$ was macerated in ethanol $(20 \mathrm{~mL})$ each for 3 days and filtered. The solvent was evaporated using a rotary evaporator to obtain viscous semi-solid crude. The semi-dry ethanolic crude extract was subjected to GC-MS analysis.

\section{NMR profiling of honey}

Honey was extracted following the procedure reported by Vit et al. ${ }^{15}$ Chloroform $(10 \mathrm{~mL})$. was added into a centrifuge tube containing honey $(20 \mathrm{~g})$ in deionized water $(10 \mathrm{~mL})$. The mixture was stirred for $10 \mathrm{~min}$ and centrifuge at 10,000 $\mathrm{x}$ g at $4{ }^{\circ} \mathrm{C}$ for $15 \mathrm{~min}$. The organic layer was separated and evaporated under nitrogen atmosphere to produce solid and analyzed using ${ }^{1} \mathrm{H}-\mathrm{NMR}$ spectroscopy.

\section{Analysis of glucose in honey}

Honey with a concentration of $10 \%(\mathrm{v} / \mathrm{v})$ was prepared by adding ultrapure water $(9 \mathrm{~mL})$ to honey $(1 \mathrm{~mL})$. The mixture was filtered via filter paper $(0.45 \mu \mathrm{m})$ before analysis using HPLC.

\section{Extraction of the environmental contaminant in honey}

Wet acid digestion of honey was carried out in open vessels following Qadar et al. ${ }^{16}$ Nitric acid $(2 \mathrm{~mL}, 0.1 \mathrm{M})$ was added into a beaker containing honey $(1 \mathrm{~g})$. The mixture was heated to reduce volume from $2 \mathrm{~mL}$ to near dryness at 0.05 $\mathrm{mL}$. Nitric acid $(10 \mathrm{~mL}, 0.1 \mathrm{M})$ was added into the residue, followed by distilled water to give a $25 \mathrm{~mL}$ solution mixture. The digest was filtered through $0.45 \mu \mathrm{m}$ filter paper before analysis using ICP-OES.

\section{Antibacterial activity}

Disc diffusion assay was performed on honey in the culture medium of Staphylococcus aureus (S. aureus, N5923) ${ }^{17}$ and E. coli (ATCC 25922) ${ }^{18}$ with some modification. ${ }^{19}$ These bacteria were used in Mueller-Hinton broth as inoculum and incubated overnight at $37^{\circ} \mathrm{C}$ with constant shaking at 200 $\mathrm{rpm}$. The suspension bacteria (100 $\mu \mathrm{L}$ of target strain) were inoculated on a Mueller-Hinton agar plate and spread thinly with a sterile cotton-tipped swab. A sterile filter paper (6 $\mathrm{mm}$ diameter) was soaked with honey $(20 \mu \mathrm{L})$, while sterile distilled water-loaded disc and ampicillin was used as the negative and positive control, respectively. The plate was incubated for $24 \mathrm{hr}$ at $37{ }^{\circ} \mathrm{C}$ and the inhibition zones were measured in millimetres $(\mathrm{mm})$. 


\section{Antioxidant activity}

The stingless bee honey's free radical scavenging activity was determined using the 2,2- diphenyl-1-picrylhydrazyl (DPPH) solution in methanol. ${ }^{20}$ The solution was added into the concentration of honey in methanol $(50,100$ and $200 \mathrm{ppm}$ ). The absorbance was measured at $517 \mathrm{~nm}$ using UV-Visible spectrometer Optima SP-300. The lower absorbance value indicates higher radical scavenging activity. The activity was compared with Tualang honey and ascorbic acid was used as the positive control. The antioxidant activity is calculated in Eq. 1.

Scavenging activity $(\%)=\frac{\text { Blank absorbance }- \text { sample absorbance }}{\text { Blank absorbance }} \times 100 \quad$ (Eq. 1)

\section{RESULTS}

\section{Physicochemical properties and chemical pro- filing of honey and plant}

The honey samples were collected from three different locations at Serapi Garden Sarawak, a botanical farm in Borneo, which is surrounded by predominant floral sources such as A. carambola and A. leptopus. The chemical profiling of the honey and plants were subjected to GC-MS analysis to intercorrelate the properties and different classes of compounds present in all extracts (Table 1).

Table 1: Bioactive compounds in honey and plants and their biological properties

\begin{tabular}{|c|c|c|}
\hline Compound & Class & $\begin{array}{l}\text { Biological } \\
\text { properties }\end{array}$ \\
\hline \multicolumn{3}{|l|}{ Honey extract } \\
\hline 1-Hexadecanol & Fatty alcohol & Antioxidant ${ }^{21}$ \\
\hline 2,4-Di-tert-butylphenol & Phenol & $\begin{array}{l}\text { Antibacterial, } \\
\text { anti-inflammatory, } \\
\text { antioxidant }^{22}\end{array}$ \\
\hline 1-Nonadecene & Alkene & $\begin{array}{l}\text { Antimicrobial, anti- } \\
\text { oxidant, anticancer }\end{array}$ \\
\hline 1-Docosanol & Fatty alcohol & Antiviral $^{23}$ \\
\hline 1-Tetracosanol & Fatty alcohol & Antioxidant ${ }^{22}$ \\
\hline 13-Docosenamide,(Z)- & Fatty amides & Antimicrobial $^{24}$ \\
\hline 1-Heptacosanol & Fatty alcohol & $\begin{array}{l}\text { Anticancer, antioxi- } \\
\text { dant, antimicrobial }{ }^{25}\end{array}$ \\
\hline Tetrapentacontane & Alkane & Antimicrobial $^{26}$ \\
\hline \multicolumn{3}{|c|}{ Plant Extract: Averrhoa carambola } \\
\hline 2,4-Di-tert-butylphenol & Phenol & $\begin{array}{l}\text { Antibacterial, anti- } \\
\text { inflammatory }^{22}\end{array}$ \\
\hline 1-Nonadecene & Alkene & $\begin{array}{l}\text { Antimicrobial, anti- } \\
\text { oxidant, anticancer }{ }^{22}\end{array}$ \\
\hline 3-Pentadecylphenol & Alkylphenol & Antibacterial $^{27}$ \\
\hline
\end{tabular}

Table 1: (Continued)

\begin{tabular}{|c|c|c|}
\hline Compound & Class & $\begin{array}{l}\text { Biological } \\
\text { properties }\end{array}$ \\
\hline Lupeol & Triterpenoids & $\begin{array}{l}\text { Anti-inflammatory, } \\
\text { anticancer }^{28}\end{array}$ \\
\hline 1-Heptacosanol & Fatty alcohol & $\begin{array}{l}\text { Anticancer, antioxi- } \\
\text { dant, antimicrobial }{ }^{25}\end{array}$ \\
\hline \multicolumn{3}{|c|}{ Plant Extract: Antigonon leptopus } \\
\hline 2,4-Di-tert-butylphenol & Phenol & $\begin{array}{l}\text { Antibacterial, anti- } \\
\text { inflammatory }^{22}\end{array}$ \\
\hline 1-Heptadecene & Alkene & $\begin{array}{l}\text { Anticancer, antioxi- } \\
\text { dant, antimicrobial }^{22}\end{array}$ \\
\hline 1-Nonadecene & Alkene & $\begin{array}{l}\text { Antimicrobial, anti- } \\
\text { oxidant, anticancer }^{22}\end{array}$ \\
\hline $\begin{array}{l}\text { 9-octadecenoic acid } \\
\text { and hexadecanoic acid } \\
\text { methyl ester }\end{array}$ & Fatty ester & $\begin{array}{l}\text { Antibacterial, antial- } \\
\text { lergic }^{24}\end{array}$ \\
\hline $\begin{array}{l}\text { 9,12-Octadecanoic acid } \\
(\mathrm{Z}, \mathrm{Z})-\text {, ethyl ester }\end{array}$ & Fatty ester & $\begin{array}{l}\text { Anti-histamine, } \\
\text { hepatoprotective }^{29}\end{array}$ \\
\hline 1-Heptacosanol & Alcohol & $\begin{array}{l}\text { Anticancer, antioxi- } \\
\text { dant, antimicrobial }{ }^{25}\end{array}$ \\
\hline
\end{tabular}

\section{The sugar contents of honey}

Glucose is known to be the primary source of energy in the diet. High glucose content, however, could cause cardiovascular diseases, diabetes and weight gain in humans. ${ }^{30} \mathrm{~A}$ comparison of the glucose content from Borneo H. itama honey is depicted in Table 2.

Table 2: Comparison of glucose content from Borneo H. itama honey (Serapi Garden)

\begin{tabular}{llc} 
Location & Samples & $\begin{array}{c}\text { Glucose } \\
(\mathrm{g} / \mathrm{L})\end{array}$ \\
& Honey SGo1 & 61.65 \\
Serapi Garden & Honey SGo2 & 147.44 \\
& Honey SGo3 & 96.72 \\
& Kelulut honey (Heterotrigona & 92.20 \\
& itama) & \\
Peninsular & Tualang honey (Apis spp.) & 300.70 \\
${\text { Malaysia }{ }^{11}}$ & \\
& Gelam honey (Apis spp.) & 328.50 \\
& Pineapple honey (Apis spp.) & 372.00 \\
Brazil32 $^{2}$ & Melipona subnitida honey & $377.00-$ \\
& & 457.00 \\
& Melipona scutellaris honey & $381.00-$ \\
& & 433.00 \\
\hline
\end{tabular}

n.d: not detected

The honey of H. itama from Borneo Serapi Garden gave lower glucose content $(61.65-147.44 \mathrm{~g} / \mathrm{L})$ than the honey from Brazil ( $377.00-453.00 \mathrm{~g} / \mathrm{L}){ }^{32}$ The glucose content 
was also lower than the stingless bee and Apis sp. bees honey from Peninsular Malaysia, with the reported glucose content of $92.20-372.00 \mathrm{~g} / \mathrm{L}^{31}$

\section{Environmental Contaminants}

The concentration of heavy metals in honey may be from the nectar and pollen gathered by the bees or absorbed from the atmosphere and transferred to their hive. ${ }^{33}$ The mean of heavy metal concentrations of the stingless bee honey are determined and compared with the concentration of heavy metals in honey from other countries based on the standard prescription by Malaysia Food Regulations (2019) ${ }^{34}$ and Codex Alimentarius Commission ${ }^{35}$, as shown in Table 3.

Table 3: Heavy metals concentration in honey from various locations ${ }^{36-38}$

\begin{tabular}{|c|c|c|c|c|c|}
\hline \multirow{2}{*}{$\begin{array}{l}\text { Types of heavy } \\
\text { metals }\end{array}$} & \multirow{2}{*}{$\begin{array}{l}\text { The permissible limit } \\
\text { for stingless bee product } \\
\text { (ppm) }\end{array}$} & \multicolumn{4}{|c|}{ Heavy metals content (ppm) } \\
\hline & & Serapi Garden & Brazil & New Zealand & China \\
\hline $\mathrm{Zn}$ & 15.0 & $0.084-0.204$ & $3.677-7.430$ & $0.020-2.460$ & $0.587-2.849$ \\
\hline $\mathrm{Cu}$ & 2.0 & $0.016-0.042$ & $0.125-1.065$ & $0.090-0.700$ & $0.036-0.308$ \\
\hline $\mathrm{Pb}$ & 0.30 & $0.010-0.012$ & $1.076-1.333$ & $0.010-0.040$ & $0.007-0.085$ \\
\hline As & 0.5 & n.d & - & $0.040-0.170$ & $0.01-0.08$ \\
\hline $\mathrm{Cd}$ & 0.2 & n.d & $2.034-6.533$ & $0.010-0.450$ & $0.001-0.004$ \\
\hline
\end{tabular}

n.d: not detected

\section{NMR profiling of honey}

${ }^{1} \mathrm{H}-\mathrm{NMR}$ profiling is a comprehensive method to determine the authenticity of honey. ${ }^{39}$ The ${ }^{1} \mathrm{H}-\mathrm{NMR}$ spectrum of Borneo stingless bee ( $H$. itama) honey is compared with the honey of two stingless bees (Geotrigona sp. and Scaptotrigona sp.) and honey of honeybee (Apis sp.) from Ecuador as shown in Figure 1.

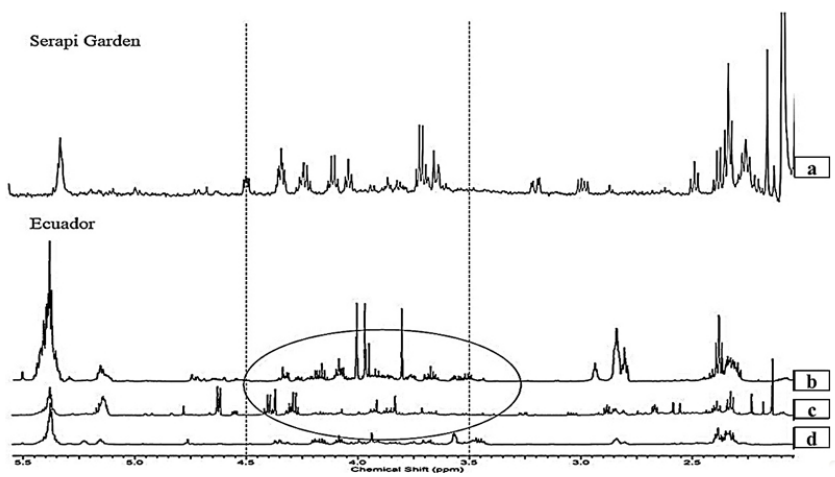

Figure 1: Comparison of expanded ${ }^{1} \mathrm{H}-\mathrm{NMR}$ spectra of honey extract produced by a) Borneo stingless bee (H. itama), b) $\mathrm{Ge}$ otrigona sp., c) Scaptotrigona sp., and d) Apis sp. bee from Ecuador.

\section{Antibacterial activity}

The high viscosity of the honey has impeded the evaluation of the antimicrobial activity of honey via turbidimetric kinetic assay. ${ }^{40}$ Alternatively, the antibacterial activity of honey was demonstrated against $S$. aureus and E. coli, via the Kir-
by-Bauer disc diffusion assay. ${ }^{17-19}$ The inhibition zones are presented in Figure 2. The inhibition zone of SG01 - SG03 was evaluated against E. coli $(9.0-19.0 \mathrm{~mm})$. However, no inhibition zone was observed against $S$. aureus. The Borneo stingless bee honey contains active compounds with excellent antimicrobial properties compared to Mexico and Kenya stingless bee honey which has no inhibition against both $E$. coli and S. aureus. ${ }^{41,42}$

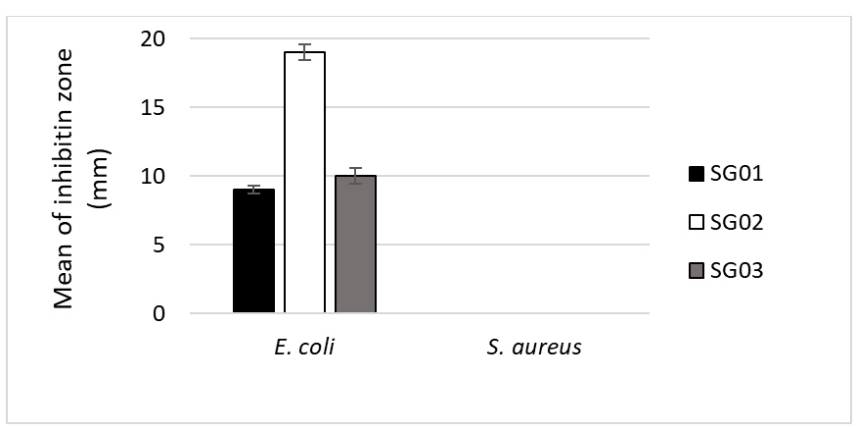

Figure 2: Mean of honey inhibition zone (SG01-SG03) against E. coli and S. aureus

\section{Antioxidant activity}

Stingless bee honey is one of the natural antioxidant resources with the potential ability to mitigate the effects of oxidative stress. ${ }^{43}$ The antioxidant activity of Borneo stingless bee honey (SG01-SG03) was evaluated using DPPH assay. ${ }^{20,44}$ Compared to Tualang honey, the Bornean H. itama honey demonstrated four times higher antioxidant activity (Figure $3)$. 


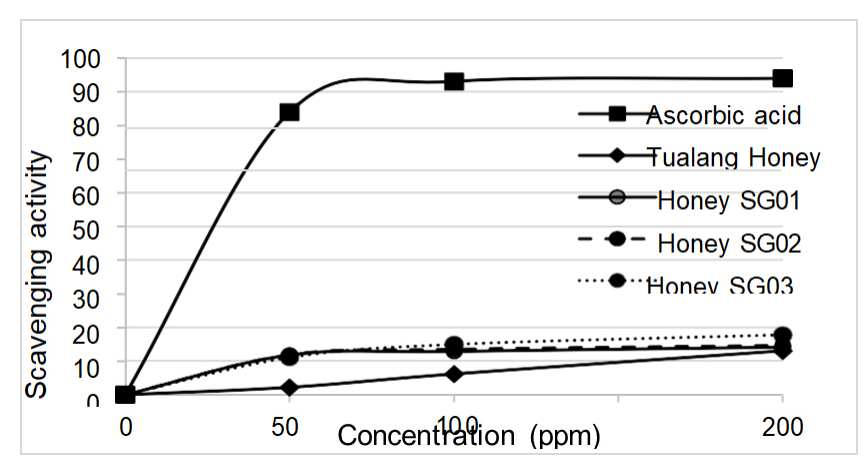

Figure 3: Antioxidant activity of honey samples from Borneo stingless bee and Tualang honey

\section{DISCUSSION}

In this study, eight bioactive compounds were identified in the Borneo stingless bee honey, where the major components are long-chain fatty alcohols, followed by hydrocarbons, phenol and fatty amides (Table 1). The hydrocarbons detected in the honey are likely yielded by ethyl acetate that was used as eluent for the extraction. ${ }^{13,14} \mathrm{~A}$ phenolic compound of 2,4-ditert- butyl-phenol was identified as the most dominant component and first timely reported from Borneo H. itama honey. The phenolic of 2,4-ditertbutyl-phenol has been reported with excellent antioxidant, antibacterial and anti-inflammatory activity. The compound has also been associated with the unique aroma of the honey. ${ }^{15}$

A comparative analysis of the plant extracts from A. carambola and A. leptopus is shown in Table 1. The compounds present in the plant extracts of $A$. carambola and A. leptopus showed a similar composition of bioactive compounds found in the honey such as 2,4-di-tert- butylphenol, 3-pentadecylphenol, 1-nonadecene and 1-heptacosanol. The composition of honey is associated with the nearest floral resources within a maximum distance of $500 \mathrm{~m} .{ }^{16-18}$ The compounds extracted from plants and their metabolites in stingless bee honey indicate the effect of the chemical compounds on the botanical origin. ${ }^{48}$ Samples from the same geographical source do not differ significantly in the composition that could be important chemical markers and authentication for honey. ${ }^{19,20}$

The quality of glucose in honey is influenced by botanical sources. Another factor such as bee species is also contributing to the difference of glucose content in honey from various places. ${ }^{51}$ Each species has its floral preferences, which could have selective effects on the evolution of nectar characteristics, thus influenced the chemical composition of honey. ${ }^{21,22}$ The glucose content in honey can spontaneously crystallize during granulation due to less solubility in water. ${ }^{23}$ The crystallization sometimes causes the misconception that the crystallized honey is adulterated ${ }^{54}$ Honey with lower glucose content is preferred as it will decrease the rate of the crystallization process in honey. ${ }^{24,25}$ Honey SG01 gave the lowest glucose content of $61.65 \mathrm{~g} / \mathrm{L}$ compared to other honey samples. The lowest value could be due to the stingless bee nest location that closes to the herbal plant with less number of flowers. The nectar sugar secretion amount from herbal plants is reported to be lesser than flower and tree species. ${ }^{26}$

Stingless bee secreted invertase enzyme to hydrolyze disaccharides into fructose, glucose, and galactose monosaccharides in nectar. These monosaccharides form the dominant composition of sugar in honey. ${ }^{27}$ The sugar content in honey is also closely interrelated to the enzymes provided by the bee. ${ }^{28}$ The ICP-OES analysis showed significantly low heavy metals content in the honey from Borneo stingless bee than the permissible limit of heavy metals for stingless bee product set by Malaysian Food Regulations ${ }^{43}$ and Codex Alimentarius Commission ${ }^{35}$ (Table 3). $\mathrm{Zn}, \mathrm{Cu}$ and $\mathrm{Pb}$ were detected in significantly low mean concentrations compared to other locations (Table 3 ). $\mathrm{Zn}$ is a predominant heavy metal presence in Borneo stingless bee honey and other places in the world such as Brazil, New Zealand and China. ${ }^{36-38}$ It could be either as environmental contaminants or natural constituents present in flowers. ${ }^{44}$ Nevertheless, the concentration of $\mathrm{Zn}$ obtained is remarkably lower than the permissible value of $\mathrm{Zn}$ in bee products which is $15.0 \mathrm{ppm} .{ }^{45}$

Borneo stingless bee honey from H. Itama has significantly lower heavy metal content compared to other countries (Table 3). The mean concentration of $\mathrm{As}$ and $\mathrm{Cd}$ is in a nontraceable amount and not detected. The location of Serapi Garden $(18.2 \mathrm{~km})$ from the city and urban areas) could be one of the factors for the trace amounts of As and $\mathrm{Cd}$ in honey samples compared to other locations. The amount of $\mathrm{Cd}$ in bee products was considerably higher in urban compared to non-residential areas. ${ }^{46-49}$ This finding is concurrent with the different botanical and geographical origins attributed to differences in environments that affect the heavy metal content in stingless bee products. ${ }^{50}$

The ${ }^{1} \mathrm{H}-\mathrm{NMR}$ peaks of honey extract observed at $3.5-4.5$ ppm showed different chemical properties of Borneo $H$. itama honey compared to Geotrigona sp., Scaptotrigona sp. and Apis sp. $^{52}$ (Figure 1) This is coherent with the GCMS analysis (Table 1) indicating a high intensity of fatty alcohols presence in Borneo stingless bee honey. The resonance in this region indicates the characteristics of the bee species, independent of floral and geographical origin. ${ }^{51}$ The resonance presence at 2.5-3.5 ppm in ${ }^{1} \mathrm{H}$ NMR spectra indicates the differences in chemical constituents of the honey sourced from diverse floral origins. ${ }^{53}$ The high density of signals present in stingless bee honey as compared to Apis sp. indicates potential chemical markers to distinguish bee species. More signals were observed in stingless bees honey due to the small size of stingless bees that allowed the accumulation of nectar from a variety of flowers, compared to Apis sp. ${ }^{58}$ The signals 
presence at $5.0-5.5 \mathrm{ppm}$ and $2.20-2.50 \mathrm{ppm}$ in honey samples represented anomeric protons of sugar. ${ }^{54-57}$ and longchain carboxylic esters ${ }^{67}$, respectively. The difference in the chromatographic and signals present in the spectra is because of the various bee populations and the specific chemical composition of honey. ${ }^{59}$ Each bee species was reported to have specific requirements and different preferences in floral sources that could affect the chemical composition of honey.

The antimicrobial analysis of Borneo stingless bee honey showed higher inhibition against $E$. coli with a maximum zone of inhibition of $19.0 \mathrm{~mm}$ compared to Manuka honey with a zone inhibition of $11.5 \mathrm{~mm} .{ }^{60-64}$ The difference in the antimicrobial properties of stingless bee honey on E. coli and $S$. aureus could be due to the bacterial cell wall and their biofilm properties.$^{65}$ S. Aureus has a thicker cell wall which causes honey to ineffectively penetrate the membrane ${ }^{66}{ }^{6}$ The highest inhibition zone $(19.0 \mathrm{~mm})$ against $E$. coli was performed by SG02, which also exhibited the highest glucose content (Table 2). High sugar content in honey can also influence the antibacterial activity similar to Manuka honey with high sugar content. ${ }^{67-71}$ The presence of phenolic compounds in stingless bee honey namely 2,4-di-tert-butyl phenol and 3- pentadecylphenol (Table 1) has also contributed to the antibacterial activities. ${ }^{22,27}$ The effectiveness of honey against bacteria is based on the chemical composition, bee species and geographical origin. ${ }^{72}$

H. itama honey from Serapi Garden showed higher antioxidant property as indicated by the lower IC50 values (12.55 $-33.78 \mathrm{ppm}$ ) than that of Tualang honey (IC50 $=54.90 \mathrm{ppm})$ and Manuka honey $($ IC50 $=68.0 \mathrm{ppm}) \cdot{ }^{73}$ Higher polyphenols content in the Borneo stingless bee honey (i.e 2,4-di-tertbutyl-phenol) is one of the main factors for the higher antioxidant activity compared to Tualang and Manuka honey. ${ }^{74}$ The 2,4-di-tertbutyl-phenol is an unsaturated cyclic compound and contributes to the free radical scavenging in stingless bee honey. ${ }^{75}$ The variability in antioxidant activity of honey samples may be attributed to the botanical background of the bees and environmental factors such as soil, temperature, humidity. ${ }^{76}$

\section{CONCLUSION}

The overall results revealed that Borneo H. Itama honey has high phenolic, aliphatic and fatty alcohols which are closely associated with the compounds that present in the predominant flowers. The geographical distance from the city and urban area, surrounded by dense flora and fauna, has contributed to the low environmental contaminant in Borneo H. itama honey compared to honey from Apis sp. and other stingless bees species from other countries. Borneo H. itama honey demonstrated active microbial inhibition against $E$. coli and higher antioxidant activity. In other words, Borneo
H. itama honey is a suitable candidate for a new therapeutic choice in the pharmaceutical industry.

\section{ACKNOWLEDGEMENTS}

Authors acknowledge the immense help received from the scholars whose articles are cited and included in references to this manuscript. The authors are also grateful to authors/editors/publishers of all those articles, journals and books from where the literature for this article has been reviewed and discussed. Special acknowledgement to Capt. (R) Md Nasir Md Zain and Mr Abdul Hisham Yusoff from Serapi Bayu Sdn Bhd and Serapi Garden, Sarawak for providing honey samples throughout the study.

CONFLICT OF INTEREST: The authors declare that they have no competing interests.

FINANCIAL SUPPORT: The work is financially supported by a grant from the Ministry of Education Malaysia F07/ FRGS/1883/2019.

\section{REFERENCES}

1. Zubaidah AH, Shamsul Bahri AR, Sanusi J, Adam NA. Ultrastructural comparison of three stingless bees species of Borneo. Malaysian J Micr 2017;13(1):8-16.

2. Jaapar MF, Halim M, Mispan MR, Jajuli R, Saranum MM, Zainuddin MY, et al. The diversity and abundance of stingless bee (Hymenoptera: Meliponini) in Peninsular Malaysia. Adv in Envi Bio 2016;10(9):1-8.

3. Tuksitha L, Chen Y-LS, Chen Y-L, Wong K-Y, Peng C-C. The antioxidant and antibacterial capacity of stingless bee honey from Borneo (Sarawak). J Asia Pac Entomol 2018;21(2):563570.

4. Kelly N, Farisya MSN, Kumara TK, Marcela P. Species Diversity and External Nest Characteristics of Stingless Bees in Meliponiculture. Pertanika J Tropical Agri Sci 2014;37(3):293298.

5. Harun A, Zaaba SK, Kamarudin LM, Zakaria A, Farook RSM, Ndzi DL, et al. Stingless bee colony health sensing through integrated wireless system. J Teknologi 2015;77(28):85-90.

6. Abd Jalil MA, Kasmuri AR, Hadi H. Stingless bee honey, the natural wound healer: A review. Skin Pharmacol Physiol 2017;30(2):66-75.

7. Kothai S, Jayanthi B. Evaluation of Antioxidant and Antimicrobial Activity of Stingless Bee Propolis (Tetragonula iridipennis) of Tamilnadu, India. Int J Pharmacy and Pharma Sci 2014;6(8):81-85.

8. Yaacob M, Rajab NF, Shahar S, Sharif R. Stingless bee honey and its potential value: a systematic review. Food Res 2018;2(2):124-133.

9. Zainol MI, Mohd Yusoff K, Mohd Yusof MY. Antibacterial activity of selected Malaysian honey. BMC Complement Altern Med 2013;13(1):129.

10. Osés SM, Pascual-Maté A, Fernández-Muiño MA, López-Díaz TM, Sancho MT. Bioactive properties of honey with propolis. Food Chem 2016;196:1215-1223. 
11. Alvarez-Suarez JM, Tulipani S, Díaz D, Estevez Y, Romandini $\mathrm{S}$, Giampieri F, et al. The antioxidant and antimicrobial capacity of several monofloral Cuban honeys and their correlation with colour, polyphenol content and other chemical compounds. Food Chem Toxicol. 2010;48(8-9):2490-2499.

12. Razali MTA, Zainal ZA, Maulidiani M, Shaari K, Zamri Z, Mohd Idrus MZ, et al. Classification of Raw Stingless Bee Honeys by Bee Species Origins Using the NMR- and LC- MS-Based Metabolomics Approach. Molecules 2018;23(9):2160.

13. Alvarez-Suarez JM, Tulipani S, Romandini S, Bertoli E, Battino M. Contribution of honey in nutrition and human health: a review. Med J Nutrition Metab 2010;3(1):15-23.

14. Nurul SMS, Gan SH, Halim AS. Analysis of volatile compounds of Malaysian tualang (Koompassia excelsa) honey using gas chromatography, mass spectrometry. African J Tradit Complem Altern Med 2013;10(2):180-188.

15. Vit P, Uddin J, Zuccato V, Maza FR, Schievano E. Entomological Origin of Honey Discriminated by NMR Chloroform Extracts in Ecuadorian Honey. Int J Biol Biomol Agri Food Biotech Engg 2015;9(5):494-497.

16. Qadar S, Noor A, Maming. Mineral Content and Physico-Chemical Characteristics in Terasa's Forest Honey. Marina Chimica Acta 2016;17(1):1-6.

17. Insan NG, Payal N, Singh M, Yadav A, Chaudhary BL, Srivastava A. Post operative wound infection: Bacteriology and antibiotic sensitivity pattern. Int J Cur Res Rev 2013;5(13):74-79.

18. Rahim N, Mail MH, Omar EA, Lamin RAC, Nazli SN, Sabri N, et al. Antibacterial properties of honey and propolis produced by both heterotrigona itama and geniotrigona thoracica stingless bee. Asian J Micro Biotech Envt Sci 2018;20:376-379.

19. Halim AN, Ngaini Z. Synthesis and characterization of halogenated bis(acyl-thiourea) derivatives and their antibacterial activities. Phosp Sulf Silicon Related Elem 2017;192(9):1012-1017.

20. Saini P, Singh P, Dubey S, Srivastava A. Effect of different processing methods on polyphenolic content and antioxidant activity of broad beans (Vicia faba). Int J Curr Res Rev 2016;8(13):16.

21. Kumaradevan G, Damodaran R, Mani P, Dineshkumar G, Jayaseelan T. Phytochemical screening and GC-MS analysis of bioactive components of ethanol leaves extract of Clerodendrum phlomidis (L.). Am J Bio Pharma Res 2015;2(3):142-148.

22. Amudha P, Jayalaksmi M, Pushpabharathi N, Vanitha V. Identification of Bioactive Components in Enhalus acoroides Seagrass Extract by Gas Chromatography-Mass Spectrometry. Asian J Pharma Clin Res 2018;11(10):313-317.

23. Abdel-Haq N, Chearskul P, Al-Tatari H, Asmar B. New antiviral agents. Ind J Pediatr 2006;73(4):313-321.

24. Rukshana MS, Doss A, Kumari PR. Phytochemical screening and GC-MS ANALYSIS of leaf extract of Pergularia daemia (Forssk) Chiov. Asian J Plant Sci Res 2017;7(1):9-15.

25. Venkata RB, Samuel LA, Pardha SM, Rao NB, Naga A, Sudhakar M, et al. Antibacterial, antioxidant activity and GC-MS analysis of Eupatorium odoratum. Asian J Pharma Clin Res 2012;5(2):99-106.

26. Xuanji X, Zengjun G, Hui Z, Xia L, Jun L, Dandan L, et al. Chemical composition, in vitro antioxidant activity and $\alpha$-glucosidase inhibitory effects of the essential oil and methanolic extract of Elsholtzia densa Benth. Natural Product Res 2016;30(23):2707-2711.

27. Cieślik-Boczula K, Koll A. The effect of 3-pentadecylphenol on DPPC bilayers ATR-IR and 31P NMR studies. Biophys Chem 2009;140(1-3):51-56.

28. Casuga FP, Castillo AL, Corpuz MJ-AT. GC-MS analysis of bioactive compounds present in different extracts of an endemic plant Broussonetia luzonica (Blanco)(Moraceae) leaves. Asian Pac J Trop Biomed 2016;6(11):957-961.

29. Arora S, Meena S. GC-MS Profiling of Ceropegia bulbosa Roxb. var. bulbosa, an endangered plant from Thar Desert, Rajasthan. Pharma Innov J 2017;6(11):568-573.

30. Lineback DR, Jones JM. Sugars and health workshop: summary and conclusions. Am J Clin Nutr 2003;78(4):893S-7S.

31. Kek SP, Chin NL, Yusof YA, Tan SW, Chua LS. Classification of entomological origin of honey based on its physicochemical and antioxidant properties. Int J Food Proper 2017;20(sup3):S2723S38.

32. Sousa B, Souza dEL, Marques G, Benassi MdT, Gullón B, Pintado MM, et al. Sugar profile, physicochemical and sensory aspects of monofloral honeys produced by different stingless bee species in Brazilian semi-arid region. Food Sci Tech 2016;65:645-651.

33. Porrini C, Sabatini AG, Girotti S, Ghini S, Medrzycki P, Grillenzoni F, et al. Honey bees and bee products as monitors of the environmental contamination. Apiacta 2003;38(1):63-70.

34. Regulations MF. Food Act 1983 \& Regulations 1985, Regulation 38 - Fourteenth Schedule.

35. Kuala Lumpur, Malaysia: International Law Book Services; 2019.

36. Commission JFWCA. Standard for honey; CXS12-1981; Adopted in 1981; Revised in 1987, 2001; Amended in 2019.2019. p18.

37. Nascimento ASd, Marchini LC, Carvalho CALd, Araújo DFD, Olinda RAd, Silveira TAd.

38. Physical-Chemical Parameters of Honey of Stingless Bee (Hymenoptera: Apidae). Am Chem Sci J 2015;7(3):139-149.

39. Vanhanen LP, Emmertz A, Savage GP. Mineral analysis of mono-floral New Zealand honey.

40. Food Chem 2011;128(1):236-240.

41. Ru QM, Feng Q, He JZ. Risk assessment of heavy metals in honey consumed in Zhejiang province, southeastern China. Food Chem Toxicol 2013;53:256-262.

42. Schievano E, Peggion E, Mammi S. 1H Nuclear Magnetic Resonance Spectra of Chloroform Extracts of Honey for Chemometric Determination of Its Botanical Origin. J Agric Food Chem 2010;58(1):57-65.

43. Ngaini Z, Mortadza NA. Synthesis of halogenated azo-aspirin analogues from natural product derivatives as the potential antibacterial agents. Natural Product Res 2019;33(24):3507-3514.

44. Muli EM, Maingi JM. Antibacterial activity of Apis mellifera L. propolis collected in three regions of Kenya. J Venom Anim Toxins Incl Trop Dis 2007;13(3):655-663.

45. Temaru E, Shimura S, Amano K, Karasawa T. Antibacterial activity of honey from stingless honeybees (Hymenoptera; Apidae; Meliponinae). Pol J Microbiol 2007;56(4):281-285.

46. Kocot J, Kiełczykowska M, Luchowska-Kocot D, Kurzepa J, Musik I. Antioxidant potential of propolis, bee pollen, and royal jelly: Possible medical application. Oxid Med Cell Longev 2018;2018.

47. Moon JK, Shibamoto T. Antioxidant assays for plant and food components. J Agric Food Chem 2009;57(5):1655-1666.

48. Zhang H, Li N, Pan X, Wu S, Xie J. Oxidative conversion of glucose to gluconic acid by iron

49. (III) chloride in water under mild conditions. Green Chem 2016;18(8):2308-2312.

50. da Silva IAA, da Silva TMS, Camara CA, Queiroz N, Magnani M, de Novais JS, et al. Phenolic profile, antioxidant activity and palynological analysis of stingless bee honey from Amazonas, Northern Brazil. Food Chem 2013;141(4):3552-3558. 
51. Shashikala A, Harini BP, Reddy MS. GC-MS analysis of phytocomponents in the methanolic extract of propolis of honey bee. Asian J Pharma Analysis Med Chem 2016;4(2):74-78.

52. Castro-Vázquez L, Díaz-Maroto MC, Pérez-Coello MS. Volatile composition and contribution to the aroma of Spanish honeydew honeys. Identification of a new chemical marker. J Agric Food Chem 2006;54(13):4809-4813.

53. Manyi-Loh CE, Ndip RN, Clarke AM. Volatile compounds in honey: a review on their involvement in aroma, botanical origin determination and potential biomedical activities. Int J Mol Sci 2011;12(12):9514-9532.

54. Velikova M, Bankova V, Marcucci MC, Tsvetkova I, Kujumgiev A. Chemical composition and biological activity of propolis from Brazilian meliponinae. Zeitschrift für Naturforschung C 2000;55(9-10):785-789.

55. Olaitan PB, Adeleke OE, Ola IO. Honey: a reservoir for microorganisms and an inhibitory agent for microbes. Afr Health Sci 2007;7(3):159-165.

56. Basari N, Ramli SN, Mohd Khairi NAS. Food Reward and Distance Influence the Foraging Pattern of Stingless Bee, Heterotrigona itama. Insects 2018;9(4):138.

57. Buba F, Gidado A, Shugaba A. Analysis of biochemical composition of honey samples from North-East Nigeria. Biochem Anal Biochem 2013;2(3):139.

58. Ozkok D, Silici S. Effects of Crystallization on Antioxidant Property of Honey. J Apitherapy 2018;4(1):24-30.

59. Nurul Zaizuliana RA, Anis Mastura AF, Jamil ZA, Norshazila $\mathrm{S}$, Zarinah Z. Effect of storage conditions on the crystallisation behaviour of selected Malaysian honeys. Int Food Res J 2017;24(Suppl.):S475-S80.

60. Adgaba N, Al-Ghamdi A, Tadesse Y, Getachew A, Awad AM, Ansari MJ, et al. Nectar secretion dynamics and honey production potentials of some major honey plants in Saudi Arabia. Saudi J Biol Sci 2017;24(1):180-191.

61. Almeida-Muradian LBd, Matsuda AH, Bastos DHM. Physicochemical parameters of Amazon Melipona honey. Química Nova 2007;30(3):707-708.

62. Kek SP, Chin NL, Tan SW, Yusof YA, Chua LS. Classification of honey from its bee origin via chemical profiles and mineral content. Food Ana Methods 2017;10(1):19-30.

63. Mehdi Y, Mutlaq A, Al-Balas Q, Azzi E, Bouadjela L, Taïbi N, et al. Physicochemical characterization and determination of chloramphenicol residues and heavy metals in Algerian honeys. Envt Sci Pollution Res. 2018;25(33):33322-33333.

64. Aghamirlou HM, Khadem M, Rahmani A, Sadeghian M, Mahvi AH, Akbarzadeh A, et al.

65. Heavy metals determination in honey samples using inductively coupled plasma-optical emission spectrometry. J Envt Health Sci Engg 2015;13(1):39.

66. Perugini M, Manera M, Grotta L, Abete MC, Tarasco R, Amorena $\mathrm{M}$. Heavy Metal $(\mathrm{Hg}, \mathrm{Cr}, \mathrm{Cd}$, and $\mathrm{Pb}$ ) Contamination in Urban Areas and Wildlife Reserves: Honeybees as Bioindicators. Biol Trace Elem Res 2011;140(2):170-176.

67. Silici S, Ünlü M, Vardar-Ünlü G. Antibacterial activity and phytochemical evidence for the plant origin of Turkish propolis from different regions. World J Micro Biotech 2007;23(12):17971803.
68. Rashed MN, Soltan ME. Major and trace elements in different types of Egyptian mono-floral and non-floral bee honeys. J Food Compost Anal 2004;17(6):725-735.

69. Olawode EO, Tandlich R, Cambray G. 1H-NMR Profiling and Chemometric Analysis of Selected Honeys from South Africa, Zambia, and Slovakia. Molecules 2018;23(3):578.

70. Ranneh Y, Ali F, Zarei M, Akim AM, Hamid HA, Khazaai H. Malaysian stingless bee and Tualang honeys: A comparative characterization of total antioxidant capacity and phenolic profile using liquid chromatography-mass spectrometry. Food Sci Tech 2018;89:1-9.

71. Spiteri M, Jamin E, Thomas F, Rebours A, Lees M, Rogers KM, et al. Fast and global authenticity screening of honey using $1 \mathrm{H}-$ NMR profiling. Food Chem 2015;189:60-66.

72. Zuccato V, Finotello C, Menegazzo I, Peccolo G, Schievano E. Entomological authentication of stingless bee honey by $1 \mathrm{H}$ NMR-based metabolomics approach. Food Control 2017;82:145-153.

73. Aween MM, Hassan Z, Faujan NH, Emdakim M, Muhialdin B. Potency of Honey as antibacterial against multiple antibiotic resistant pathogens evaluated by different methods. Am J App Sci 2014; 11:1773-1783.

74. Akca AE, Akca G, Topçu FT, Macit E, Pikdöken L, Özgen IŞ. The Comparative Evaluation of the Antimicrobial Effect of Propolis with Chlorhexidine against Oral Pathogens: An In Vitro Study. BioMed Res Int 2016;2016:3627463.

75. Lopez-Romero JC, González-Ríos H, Borges A, Simões M. Antibacterial Effects and Mode of Action of Selected Essential Oils Components against $<\mathrm{i}>$ Escherichia coli $</ \mathrm{i}>$ and

76. $<\mathrm{i}>$ Staphylococcus aureus $</ \mathrm{i}>$. Evid Based Complement Alternat Med. 2015;2015:795435.

77. Mandal MD, Mandal S. Honey: its medicinal property and antibacterial activity. Asian Pac J Trop Biomed 2011;1(2):154-160.

78. Miorin PL, Levy Junior NC, Custodio AR, Bretz WA, Marcucci MC. Antibacterial activity of honey and propolis from Apis mellifera and Tetragonisca angustula against Staphylococcus aureus. J Appl Microbiol 2003;95(5):913-920.

79. Stagos D, Soulitsiotis N, Tsadila C, Papaeconomou S, Arvanitis C, Ntontos A, et al.

80. Antibacterial and antioxidant activity of different types of honey derived from Mount Olympus in Greece. Int J Mol Med 2018;42(2):726-734.

81. Biluca FC, Braghini F, Gonzaga LV, Costa ACO, Fett R. Physicochemical profiles, minerals and bioactive compounds of stingless bee honey (Meliponinae). J Food Compost Anal 2016;50:61-69.

82. Prakash A, Suneetha V. Punica granatum (Pomegranate) rind extract as a potent substitute for L-ascorbic acid with respect to the antioxidant activity. Res J Pharm, Bio Chem Sci 2014;5:597603.

83. Maurya S, Kushwaha AK, Singh S, Singh G. An overview on antioxidative potential of honey from different flora and geographical origins. Ind J Natural Prod Resour 2014;5:9-19. 